\title{
MENINGKATNYA PEKERJA ANAK (Studi Konsep Maslahah)
}

\section{Indar Wahyuni}

Sekolah Tinggi Agama Islam (STAI) Pati

Email: azkiyaalyani@gmail.com

\begin{abstract}
Childhood is a growth process both physical and psyche, then ideally the children should be protected from from various behaviors that interfere with the growth. Therefore, the children's rights should be guaranteed such as getting health, education and play. Then, there are many factors causing the existence of child labor. And poverty case is mentioned as the main factor that led to the emergence of child labor. Moreover, the risk and the impact of children's involvement in work, means everything that experienced and felt annoying up to harm their physical and psychological. Although the poverty is often used as a reason of the child labor, but all of it are seized the child's rights. The child who works before their age will make weak next generation. It is not apropriate with maqasid asy-Syari'ah concept, one of them keep the five things, including one of $d$; haruriyyah need that keep the child's psyche. It is strenghtened by the quotation from the Qur'an. The impact of child labor in both short time and long time, of course it is so damage their both physical and psychological as stated in Q.S. an-Nisa'(4): 9. It becomes a base of why child labour is not allowed. It is as mental protection form which is a d\}haruriyyah need. Although the child labour can help the family economic for live, in other case child labour must be avoided considering the disadvantage is bigger than its advantage. Meanwhile, if it is in order to help parent and does not interfere both their mental and their physical then it is allowed.
\end{abstract}

Keyword: Child, child labour, maslahah/goodness 


\section{A. Latar Belakang}

Anak ${ }^{1}$ adalah amanah dan karunia Allah yang maha kuasa, yang dalam dirinya melekat harkat dan martabat sebagai manusia seutuhnya. Namun ternyata di sekeliling kita banyak anak kurang beruntung yang terpaksa mempertahankan hidup dengan bekerja, dalam usia terlalu muda yang lebih dikenal dengan Pekerja Anak. ${ }^{2}$ Adapun istilah pekerja adalah setiap orang yang bekerja dengan menerima upah atau imbalan dalam bentuk lain. ${ }^{3}$ Anak merupakan penerus cita-cita perjuangan bangsa yang memiliki peran strategis dan mempunyai ciri dan sifat khusus yang diharapkan dapat menjamin eksistensi bangsa dan negara di masa depan. Oleh karena itu anak punya hak untuk mendapatkan kesempatan seluas-luasnya untuk tumbuh dan berkembang secara optimal, baik secara fisik, mental maupun sosial dan mempunyai akhlak yang mulia. Karena sejak dalam kandunganpun mereka punya hak untuk hidup. ${ }^{4}$

Adapun adanya pekerja anak banyak faktor yang menyebabkan keberadaannya. ${ }^{5}$ Dan faktor kemiskinan disebut-sebut sebagai faktor utama yang menyebabkan munculnya pekerja anak. ${ }^{6}$ Belum lagi resiko dan dampak keterlibatan anak dalam kerja, dalam arti segala hal yang dialami dan dirasakan mengganggu hingga membahayakan terhadap fisik dan psikis mereka. ${ }^{7}$

Mengingat masa anak-anak merupakan proses pertumbuhan, baik fisik maupun jiwa maka idealnya anak-anak harus terhindar dari berbagai perilaku yang mengganggu pertumbuhan tersebut. Oleh karena itu, anak-anak perlu dijamin hak-haknya seperti mendapat kesehatan, pendidikan, dan bermain. ${ }^{8}$

Akan tetapi, tidak sedikit anak-anak yang harus kehilangan hak-haknya. Salah satu bentuk hilangnya hak-hak anak adalah cepatnya anak terjun untuk bekerja, padahal besarnya dampak yang buruk terhadap anak-anak terutama eksploitasi ekstrem seperti: pelacuran atau bekerja di lingkungan berbahaya kiranya keadaan tersebut harus ditindak sesuai hukum yang berlaku. ${ }^{9}$

Namun dalam kenyataan kehidupan sosial tidak semua orang tua mempunyai kesanggupan dan kemampuan penuh untuk memenuhi kebutuhan pokok anak dalam rangka mewujudkan

1 WJS. Poerwadarminto, 1982, Kamus Besar Indonesia, Jakarta: Balai Pustaka, hlm. 339, Pengertian anak secara umum adalah keturunan dari Ayah dan Ibu, sekalipun dari hubungan yang tidak sah menurut kacamata fiqh. Dalam UU ketenagakerjaan No.13 Th 2003 yang di maksud anak adalah setiap orang yang berumur di bawah 18 (delapan belas) tahun.

2SAMIN, 1998, Pekerja Anak dan Penanggulangannya, Yogyakarta: Sekretariat Anak Merdeka Indonesia, hlm. 3.

3 UU Ketenagakerjaan No.13 Th.2003, pasal 1.

4 Dinas Sosial Propinsi DIY, "Perlindungan Anak oleh Negara dan Proses Pengangkatan Anak", makalah disampaikan Pada Seminar Nasional dan Rakernas FK-MASI, (Yogyakarta: 2005), hlm.1.

5 Bagong Suyanto, 2003, Pelanggaran Hak dan Perlindungan Sosial bagi Anak Rawan, cet.ke-1 Surabaya: Airlangga Press, hlm. 25.

6 Indrasari Djandraningsih dan Popon Anarita, 2002, Pekerja Anak di Perkebunan Tembakau, Bandung: AKATIGA, hlm. 8.

7 Indrasari Djandraningsih dan Popon Anarita, 2002, Pekerja Anak di Perkebunan Tembakau, Bandung: AKATIGA, hlm.124.

8 Hardius Usman Nachrowi Djalal Nachrowi, 2004, Pekerja Anak di Indonesia: Kondisi Determinan dan Eksploitasi : Kajian Kuantitatif, Jakarta: PT Grasindo Widiasarana Indonesia, hlm.185.

9 Hardius Usman Nachrowi Djalal Nachrowi, 2004, Pekerja Anak di Indonesia: Kondisi Determinan dan Eksploitasi : Kajian Kuantitatif, Jakarta: PT Grasindo Widiasarana Indonesia, hlm.186. 
kesejahteraan anak. Sehingga kenyataan yang demikian itu mengakibatkan anak menjadi terlantar baik secara rohani, jasmani maupun sosial. Selain itu belum terlindungi dari berbagai bentuk kekerasan dan eksploitasi, sehingga masih banyak anak-anak yang hidupnya terlantar dan tidak mendapat kesempatan memperoleh pendidikan yang wajar apalagi memadahi. ${ }^{10}$

Indonesia merupakan salah satu negara yang memiliki masalah pekerja anak di usia dini. Pekerja anak lebih banyak berasal dari keluarga miskin, dengan pendidikan yang terabaikan. Sebab anak yang bekerja tumbuh menjadi seorang dewasa yang terjebak dalam pekerjaan yang tak terlatih dan dengan upah yang sangat buruk. Membiarkan anak-anak bekerja dapat menimbulkan dampak yang buruk, baik secara fisik maupun psikis.Lebih jauh, pekerja itu akan mengganggu masa depan anak untuk mendapat kehidupan yang lebih baik. Akan tetapi pada kenyataannya negara masih belum mampu memenuhi kewajibannya untuk melindungi hakhak anak.

Persoalan Pekerja Anak memang bukan persoalan yang baru terutama di kalangan masyarakat desa yang melatih anak untuk bekerja di usia dini. ${ }^{11}$ akan tetapi, Pekerja anak (upahan) terlihat menonjol ketika sektor industri modern dikembangkan oleh kolonialisme Belanda yaitu perkebunan dan industri gula menjelang abad $20 .{ }^{12}$

Islam mempunyai karakter sosial yang mendasar, dan keluarga adalah inti masyarakatnya. Islam mewajibkan hubungan dengan orang tua dengan mendefinisikan hak dan kewajiban antara satu dengan yang lainnya. ${ }^{13}$ Anak adalah makhluk yang lemah dan tidak berdaya, dan memerlukan kasih sayang tapi di dalam prakteknya tidak sedikit anak yang tidak mendapatkan atau kurang mendapatkan perhatian yang semestinya dari keluarganya.

Kalau kemudian anak bekerja tanpa mempedulikan kondisi mereka, dimana peran atau tanggung jawab orang tua yang punya kewajiban untuk melindunginya. Sesungguhnya tanggung jawab orang tua untuk menafkahi anaknya. dalam firman Allah telah disebutkan:

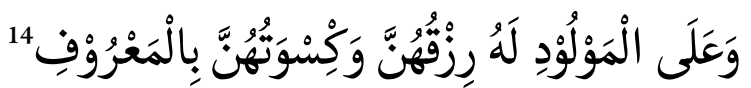

Ayat di atas menjelaskan orang tua mempunyai tugas untuk menafkahi anaknya dan apabila orang tua tidak mampu maka nafkah itu dibebankan kepada kerabatnya baik muhrim maupun bukan muhrim yang mampu. ${ }^{15}$ Semua anak dilahirkan dengan derajat yang sama, dan mempunyai hak yang sama, maka kita harus berusaha agar dasar kesamaan ini terjamin realisasinya, terlepas dari semua perbedaan mengenai jenis kelamin, latar belakang keluarga,

10 Hardius Usman Nachrowi Djalal Nachrowi, 2004, Pekerja Anak di Indonesia: Kondisi Determinan dan Eksploitasi : Kajian Kuantitatif, Jakarta: PT Grasindo Widiasarana Indonesia, hlm. 2.

11 Bagong Suyanto, 2003, Pekerja Anak dan kelangsungan Pendidikannya, cet. Ke-1, Surabaya: Airlangga Press, hlm.21.

12 Yayasan Sekretariat Anak Merdeka Indonesia, 1998, Pekerja Anak dan Penanggulangannya, Yogyakarta: Samin, hlm. 3.

13 Ali Yafie, 1997, Teologi Sosial: Telaah Kritis Persoalan Agama dan Kemanusiaan, Yogyakarta: LKPSM, hlm. 7.

$14 \mathrm{Al}$-Baqarah (2) : 233.

15 Zakariyya Ahmad al- Barri, t.t., Ahkam al-Aulad fi al-Islam, Jakarta: Bulan Bintang, hlm.57. 
status sosial dan ekonomi, golongan kebudayaan, bahasa dan agama. ${ }^{16}$ Dalam ajaran Islam juga dinyatakan bahwa tugas orang tua terhadap anaknya adalah memenuhi kebutuhan anak-anaknya baik materiil (materi ataupun immaterial, dan kebutuhan immaterial adalah berupa cinta kasih sayang yang merupakan faktor utama dalam pembentukan kepribadian anak. ${ }^{17}$

Kita seharusnya merasa prihatin kondisi pekerja anak yang semakin meningkat dan memburuk, maka dari itu sudah seharusnya Hukum Islam ikut berkontribusi untuk menjawab persoalan yang dihadapi Pekerja anak, karena sejauh ini Hukum Islam dalam merespon tentang persoalan Pekerja Anak belum secara rinci. Dalam Undang undang No. 23 Tahun 2002 tentang Perlindungan Anak juga menjelaskan kewajiban keluarga dan orang tua untuk tetap melindungi dan merawat hingga mereka tumbuh dewasa. Begitu juga dalam Undang-undang No.4 tahun 1979 tentang kesejahteraan anak yang menjelaskan bahwa anak berhak atas kesejahteraan, perawatan, asuhan dan bimbingan berdasarkan kasih sayang baik dalam keluarganya maupun dalam asuhan khusus untuk tumbuh dan berkembang secara wajar. ${ }^{18}$ Namun realitas yang terjadi ribuan anak yang seharusnya mendapat haknya mereka harus bekerja. ${ }^{19}$

Realitas yang terjadi sungguh memprihatinkan Pekerja anak semakin membanjir baik karena keinginannya sendiri atau karena paksaan dari orang tua, tidak sedikit yang kemudian menjadi pekerja seks komersial. Selain itu banyak Pekerja anak dari daerah pedesaan baik di sentra-sentra industri kecil yang berlokasi di tengah pemukiman penduduk yang secara tidak langsung mendorong mereka ikut bekerja tanpa mengesampingkan kemungkinan eksploitasi oleh orang tua terhadap mereka. ${ }^{20}$

Anak-anak Indonesia mayoritas adalah anak-anak muslim. Dalam hubungannya ini wajar kiranya kalau pembahasan pembinanan anak khususnya persoalan pekerja anak merujuk kepada nilai-nilai Islam. Bagaimana pandangan Islam terhadap Anak merupakan titik awal dari keseluruhan permasalahan pembinaan anak. ${ }^{21}$

\section{B. Kerangka Teoretik}

Adapun kerangka teoretik dalam tulisan ini adalah menggunakan nash-nash dalam alQuran yang berhubungan dengan pokok masalah. Anak, adalah tanggung jawab orang tua untuk melindunginya dan tidak membiarkan anak bekerja atau mempekerjakannya. Islam melarang pembunuhan anak dengan alasan apapun, baik karena kemiskinan, ancaman kemiskinan, atau gairah yang berlebihan akan kehormatan. Di zaman pra Islam (zaman jahiliyah) beberapa orang gadis atau anak perempuan dikuburkan hidup-hidup karena kemiskinan atau melindungi keluarga dari resiko buruk dan memalukan. al-Quran mencela hal itu dengan sangat keras.

16 Gaston Miharet, 1993, Hak-hak Anak untuk Memperoleh Pendidikan, alih bahasa Idris M.T. Hutapea Jakarta: Balai Pustaka, hlm.48.

17 Ahmad Rofiq, 1997, Hukum Islam di Indonesia, cet.2, Jakarta: Rajawali Pres, hlm. 240.

18 Pasal 1 ayat (1)

19 Pasal 26 ayat (1), (2).

20 Hardius Usman Nachrowi Djalal Nachrowi, Pekerja Anak, hlm. 25.

21 Ali Yafie, 1997, Teologi Sosial Telaah Kritis Persoalan Agama dan Kemanusiaan, cet. Ke-1, Yogyakarta: LKPSM, hlm. 6. 
Sesuai firman Allah:

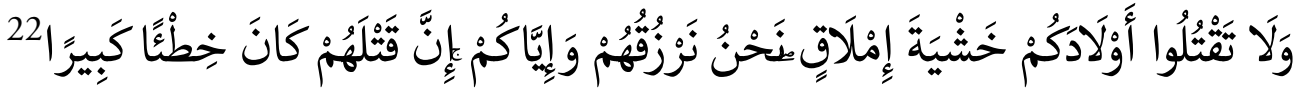

Dalam al-Quran, kehadiran anak disebut berita gembira, ${ }^{23}$ hiasan kehidupan, ${ }^{24}$ dan juga amanah ${ }^{25}$ dari Allah, sekaligus ujian bagi orang tuanya. ${ }^{26}$ Ia dilahirkan dalam keadaan fitrah sehingga orang tua berkewajiban untuk memelihara dan melindunginya dengan baik. Dalam sebuah hadits disebutkan:

$$
\text { كل مولود يولد على الفطرة فإ ن أبواه يهودانه أو ينصرانه أو يمجسانه. }
$$

Tangggung jawab ini sungguh-sungguh menjadi kewajiban orang tua sebagaimana perintah Allah untuk menjaga diri dan keluarga dari api neraka, sebagaimana firman allah:

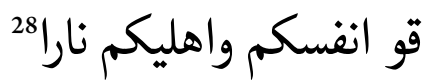

Memiliki makna kewajiban umum untuk memberi perlindungan terhadap keluarga termasuk di dalamnya anak. Di sinilah implikasi hak anak untuk mendapatkan kebutuhannya ataupun hak-hak anak kemudian muncul hubungan balik atas kewajiban orang tua untuk memberikan pemeliharaan yang baik terhadap mereka, supaya dapat berkembang dengan baik demi masa depan bangsa dan negara.

Tanggung jawab orang tua untuk memelihara anak serta kewajiban untuk melaksanakan tugas tersebut sebagai wujud konkrit taat kepada Allah, ${ }^{29}$ sebagai "jiwa" merupakan salah satu dari prinsip-prinsip Syariah, yang secara rinci asy-Syatibi menjabarkannya dalam konsep maqasid syari' ah yang terbagi ke dalam tiga bagian yaitu: daruriyyat (primer), hajiyyat (sekunder), dan tahsiniyyat (tersier). Daruriyyat memiliki tujuan untuk menjaga ad-din (agama), an-nasl (keturunan), al-mal (harta benda) dan al-aql (akal pikiran). ${ }^{30}$

Syatibi juga mendefinisikan maslahah sebagai berikut: Apa-apa yang menyangkut rizki manusia pemenuhan penghidupan manusia dan pemerolehan apa-apa yang dituntut oleh kualitas emosional dan intelektualnya, dalam pengertian mutlak, akan tetapi Syatibi juga memperhitungkan berbagai pengertian lain dimana maslahah bisa dikaji. Bagi Syatibi maslahah tidak bisa dipisahkan antara di dunia dan di akhirat, jika ada perbedaan kedua maslahah maka syara' lebih mementingkan kehidupan akherat. ${ }^{31}$ Maslahah adalah salah satu dari hal

$22 \mathrm{Al}$-Isra (17):31

23 Al-Maryam (19): 17

$24 \mathrm{Al}$-Kahfi (18):46

$25 \mathrm{Al}$-Anfal (8):26

26 At -Tagabun (64):15

27 Imam Muslim, Sahih Muslim, "Kitab qadar", "Bab Kullu min mauludin yuladu 'ala al- fitrati”. ( Beirut: dar al- Fikr, tt), II: 412, hadis dari Abi Hurairah riwayat Imam Muslim

28 At-Tahrim (66): 6.

29 Hamdan Rajih, 2002, Mengakrabkan Anak dengan Tuhan Menghantarkan Generasi Muda ke Jalan Surgawi, alih bahasa, Abdul wahid hasan Yogyakarta: Diva Press, hlm. 137.

30 Asy-Syatibi, t.t., al-Muwäfaqāt fi Usül al Ahkām, Beirut: Dār al Fikr,1341 H juz II, hlm. 2.

31 Muhammad Khalid Mas'ud, 1995, Filsafat Hukum Islam dan Perubahan Sosial, alih bahasa, W.Asmin, Surabaya: al Ikhlas, hlm. 242. 
keduniaan atau keakhiratan. Dan bahwa tuntutan yang esensial dalam konsep maslahah adalah pertimbangan dan perlindungan Unsur kedua maslahah adalah perlindungan kepentingan. Dalam hal ini tidak membiarkan anak menjadi pekerja. ${ }^{32}$

Tubuh kecil mereka adalah jiwa yang masih banyak membutuhkan hal-hal yang positif bagi pertumbuhan dan perkembangannya. Hak untuk mendapatkan pemeliharaan yang baik adalah salah satu dari hak anak yang menjadi tanggungjawab utama orang tua. Dalam keadaan orang tua sendiri tidak mampu memberi perlindungan dan pemeliharaan maka masyarakat dan negara berkewajiban penuh untuk menjamin kehidupannya dengan baik. ${ }^{33}$

Bagaimanapun anak berhak mendapatkan pemeliharaan yang baik, tumbuh dan berkembang secara wajar dan sehat, agar dapat melahirkan generasi penerus yang baik dan berkualitas bagi agama dan bangsa dan negaranya. Seperti dalam Al-Quran disebutkan

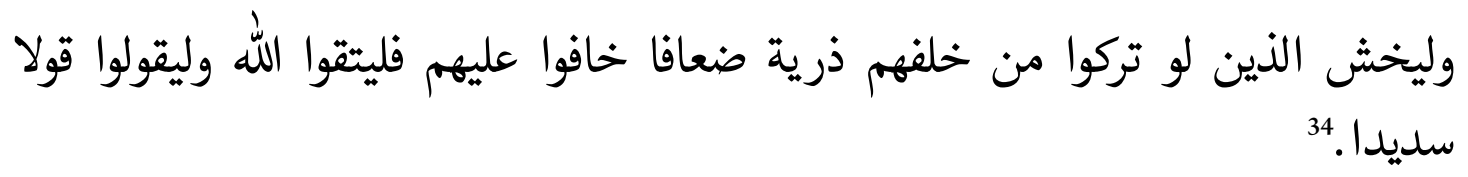

Inilah kemudian dipandang sebagai salah satu acuan untuk memperkuat pemeliharaan anak sebagai generasi penerus bangsa. Dalam Syari'ah menjelaskan menekan hal-hal yang merusak atau memadaratkan baik pada dirinya atau orang lain, adalah prinsip dasar Syari'ah.

Dalam kaidah fiqhiyyah juga dijelaskan bahwa:

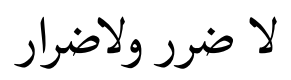

Menghilangkan madarat atau kerusakan sama artinya tidak akan membiarkan atau mendiamkan sesuatu hal yang akan melahirkan ekses negatif yang akan timbul bersamaan dengan hal tersebut, baik terhadap dirinya maupun orang lain artinya bahwa dengan adanya Pekerja Anak justru menimbulkan dampak negatif bagi perkembangan selanjutnya.

\section{Pembahasan}

\section{Tinjauan Umum Terhadap faktor-faktor Pekerja Anak}

Harus diakui selama ini masih ada budaya dalam masyarakat yang kurang menguntungkan terhadap anak. Meski belum ada rincian mengenai budaya mana saja yang merugikan anak. Tetapi sejumlah studi membuktikan bahwa masih banyak dijumpai praktek-praktek budaya yang merugikan anak baik merugikan fisik maupun emosional misalnya dalam pembiasaan bekerja sejak kecil dan juga praktek-praktek lain yang merugikan anak yang berlindung atas nama adat budaya. ${ }^{35}$

Pekerja anak menghambat anak-anak memperoleh pendidikan dan ketrampilan yang

32 Muhammad khalid masud, 1996, Filsafat Hukum Islam Studi tentang Hidup dan Pemikiran Abu Ishaq AsySyatibi, Bandung: Pustaka, hlm. 244.

33 Al- San’any, 1379 H/1960 M, Subūl as-Salām, juz 3, Kairo: al Turas al-'araby, hlm. 227.

34 An- Nisa' (4 ): 9.

35 Bagong Suyanto, 2003, Pelanggaran Hak dan Perlindungan Sosial bagi Anak Rawan, cet. ke-1 Surabaya: Airlangga Press, hlm. 18. 
dibutuhkan untuk mendapatkan pekerjaan yang layak di masa depan. Jenis pekerjaan yang sulit terdeteksi, tetapi dikategorikan Unicef sebagai eksploitasi pekerja anak adalah pembantu rumah tangga. Bahwa anak-anak yang bekerja sebagai pembantu rumah tangga kemungkinan merupakan yang paling rentan dan tereksploitasi. Sebab mereka merupakan pekerja anak yang paling rentan dan sukar dilindungi. ${ }^{36}$

Ditinjau dari dua sisi, yaitu penawaran (supply) dan permintaan (demand) sisi penawaran, ditunjukkan untuk melihat faktor-faktor yang melatarbelakangi masyarakat menyediakan tenaga anak-anak untuk bekerja, sedangkan sisi permintaan untuk menunjukkan faktor-faktor yang mendukung pengusaha atau majikan memutuskan untuk menggunakan pekerja anak sebagai faktor produksi. ${ }^{37}$

Pekerja anak merupakan sebab dan akibat dari kemiskian. Keluarga yang miskin mendorong anak-anak mereka bekerja mencari penghasilan tambahan keluarga, atau bahkan sebagai cara untuk bertahan hidup. ${ }^{38}$ Adanya pekerja anak justru mengabadikan keluarga miskin turun temurun, pertumbuhan ekonomi dan perkembangan sosial yang lambat.

Kemiskinan merupakan pendorong utama bagi anak-anak masuk ke pasar tenaga kerja, dikarenakan orang tua sangat membutuhkan tenaga anak-anaknya untuk mendapatkan penghasilan rumah tangga. ${ }^{39}$ Tetapi kenyataan menunjukkan, bahwa tidak semua orang miskin membiarkan anak-anaknya terjun ke dunia kerja. Berarti ada fakta lain, baik faktor sosial, budaya, demografi atau psikososial yang ikut mempengaruhi pekerja anak.

Putranto, dalam penelitiannya menyebutkan kemiskinan bukan faktor satu-satunya masalah pekerja anak. Bahwa kekuatan ekonomi yang mendorong anak masuk ke dalam pekerjaan di lingkungan yang membahayakan merupakan kekuatan yang paling besar dari semuanya, tetapi adat dan pola sosial yang telah berakar juga memainkan peranan.

Pandangan yang lain bahwa anak adalah harta kekayaan orang tua. Pandangan semacam ini, ketika suatu keluarga mengalami kesulitan ekonomi, anak kemudian dianggap pantas untuk disuruh membantu mencari tambahan penghasilan. Ditambahkan juga, bahwa "anak harus patuh pada orang tua" berdasarkan pandangan ini bila anak lupa menjalankan tugas membantu meringankan beban orang tua, dia akan memperoleh berbagai sanksi atau hukuman yang kemudian dapat berubah menjadi tindakan kekerasan. ${ }^{40}$

Secara struktural hubungan antara anak-anak dengan orang dewasa adalah sebuah hubungan asimetris yang tidak seimbang. Disitu anak berada dalam posisi yang lemah, lebih rendah. Karena secara fisik mereka memang lebih lemah dari pada orang dewasa, dan masih tergantung pada orang-orang dewasa yang ada di sekelilingnya. Dengan kematangan nalar,

36 Andri Yoga Utami, 2005, "Fenomena Pekerja Anak yang Terselubung dan Termarginalkan”, Jurnal Perempuan, edisi 39, Januari, hlm. 45.

37 Hardius Usman Nachrowi Djalal Nachrowi, 2004, pekerja anak di Indonesia: Kondisi Determinan dan Eksploitasi: Kajian Kuantitatif, (Jakarta: Grasindo Widiasarana Indonesia, hlm. 100.

38 Mif Baihaqi, (ed,) Anak Indonesia Teraniaya, (Bandung: Remaja Rosda Karya, 1999), hlm. xii.

39 Hardius Usman, Pekerja Anak, hlm. 101.

40 M Sumijati dkk, (ed), 2001, Manusia dan Dinamika Budaya dari Kekerasan sampai Baratayuda, Yogyakarta: Fakultas Sastra UGM, hlm. 36-37. 
kelebihan pengetahuan, dan kekuatan fisik, orang dewasa mampu memaksakan terhadap anak mengenai berbagai macam dalam hal kehidupan sehari-hari termasuk anak disuruh bekerja. Di sini anak tanpa sadar telah memproduksi hubungan asimetris yang merugikannya. ${ }^{41}$

Ketidaksetaraan, kurangnya pendidikan, ketergantungan pada usaha di bidang pertanian, transisi demographik yang lamban, budaya konsumerisme, dan gaya hidup kalangan muda mungkin lebih banyak mendorong mereka (anak-anak) menjadi pekerja seks. ${ }^{42}$

Permasalahan eksploitasi pekerja anak tanpa adanya orang-orang yang tega mengksploitasi anak-anak, maka eksploitasi tidak pernah ada. Bagaimanapun miskinnya keluarga mereka, anak-anak tidak akan dibahayakan di dalam pekerjaan, jika tidak ada orang yang siap mengekploitasinya. Masalah psikososial sebagai penyebab terjunnya anak-anak ke dunia kerja, seperti dipaksa orang tua, perilaku salah orang tua dalam mencari pengalaman. ${ }^{43}$

Pekerja anak lebih diminati karena mereka mudah diatur, mudah dididik, menurut, tidak seperti pekerja dewasa yang justru susah diatur yang menuntut gaji tinggi. Harapan pada tradisi dan budaya termasuk sebagai faktor penyebab terjadinya pekerja anak.

Walau ada banyak penjelasan yang saling berkaitan tentang pekerja anak. Tidak ada satu faktorpun yang dapat menjelaskan perkembangannya secara lengkap. Pekerja anak berkaitan dengan masalah kesempatan. Anak yang berasal dari keluarga miskin mungkin tidak punya kesempatan untuk sekolah, apalagi anak perempuan yang lebih rentan kehilangan kesempatan untuk sekolah. Karena budaya masyarakat yang mengharuskan anak perempuan bekerja di rumah. Disamping itu kemiskinan dapat mengancam keluarga dan ketentraman bangsa. ${ }^{44}$

Begitulah berbagai penyebab dan berbagai tingkatan saling berinteraksi yang menentukan jadi atau tidaknya seorang anak menjadi pekerja anak.

Perdebatan mengenai pekerja anak di tingkat Internasional mengalami kemajuan pesat dalam beberapa tahun terakhir ini yang dipicu oleh KHA. Prinsip dasar KHA yang mengakui hak anak merupakan sebuah terobosan untuk mengevaluasi pandangan selama ini mengenai anak-anak. Dari anggapan dominan bahwa anak merupakan obyek yang bersifat pasif dan segala tingkah laku serta aktivitasnya ditentukan oleh orang dewasa, KHA menawarkan sosok anak sebagai subyek aktif yang memiliki pandangan sendiri terhadap hal-hal yang menyangkut dirinya serta orang lain.

Dengan gambaran seperti itu maka anak-anak yang memiliki hak untuk menyampaikan pandangannya mengenai segala hal yang menyangkut dirinya. Kemampuan anak untuk memberikan pandangannya pada hakikatnya sejalan dengan prinsip KHA yang mengutamakan hal terbaik bagi kepentingan anak (for the best interest of the child). Dalam konteks ini berlaku logika bahwa untuk memutuskan apa yang terbaik bagi anak harus dipertimbangkan suara anak-anak sendiri.

41 M Sumijati dkk,(ed), Manusia dan Dinamika M Sumijati dkk,(ed), Manusia dan Dinamika, hlm. 44.

42 Hardius Usman, Pekerja Anak,... hlm. 101.

43 Hardius Usman, Pekerja Anak., hlm. 102.

44 Muhammad Yusuf al-Qardawy, 1996, Konsepsi Islam dalam mengentas Kemiskinan, Surabaya: Bina Ilmu, hlm. 22. 
Implikasinya, persoalan pekerja anak harus diletakkan dalam kerangka yang lebih luas dari sekadar persoalan pelanggaran hukum, pemisahan dari sekolah atau wujud kemiskinan, akan tetapi perlu dilihat dalam kerangka peran dan hak anak dalam masyarakat mengisyaratkan pemahaman kontekstual terhadap situasi dari kondisi suatu masyarakat karena perbedaan karakteristiknya. Latar belakang, kondisi sosial, ekonomi, politik dan budaya suatu masyarakat sangat mempengaruhi insiden keberadaan pekerja anak dan bangunan persoalan yang dihadapi. ${ }^{45}$

Buruknya sistem pendidikan menjadi salah satu penyebab masuknya anak dalam dunia kerja. Telaah mengenai kaitan antara pendidikan dan pekerja anak belum banyak disentuh meskipun alternatif yang sangat popular dalam mengatasi anak yang bekerja adalah memasukkan mereka ke sekolah. Kemiskinan dan buruknya pendidikan merupakan kondisi yang saling berkait, sulit dipisahkan, dan menjadi dilema dalam upaya memperbaikinya. Dalam kerangka KHA, pendidikan jelas merupakan cara utama untuk meningkatkan kesejahteraan pekerja anak. Masalahnya terletak pada kualitas, sistem, dan metode pendidikan yang seringkali tidak menarik bagi anak-anak, bahkan menyebabkan mereka terdorong masuk dunia kerja. ${ }^{46}$

Faktor lain adalah faktor kultural, sosial, ekonomi keluarga, lemahnya perangkat hukum, pengawasan dan pelaksanaannya, gejala konsumerisme akibat gencarnya promosi produkproduk industri sebagai dampak perkembangan teknologi informasi dan komunikasi sebagai penyebab bertambahnya pekerja anak. Dari sekian banyak faktor ternyata faktor lingkungan sangat menonjol, khususnya pada kasus-kasus pekerja anak di sektor pertanian. Umumnya anggota petani telah bekerja sejak dini mengikuti pola orang tua bertani secara turun temurun dari generasi ke generasi. ${ }^{47}$

Penyebab lain dari suburnya pekerja anak adalah kemudahan memalsukan dokumen identitas. Hanya dengan modal beberapa ratus ribu, seorang berusia 15 tahun bisa memiliki dokumen yang menunjukkan dirinya sudah lebih dari 18 tahun. Hal ini diungkapkan Assesment and Remediaton Manager GAP Toni Wahid. Dari ribuan pelamar ke pabrik-pabriknya, sekitar 20-30 persen merupakan anak di bawah umur dengan identitas palsu. ${ }^{48}$ Mereka bekerja karena ingin membantu orang tua atau disuruh orang tuanya. Pengertian membantu dalam konteks ini adalah anak terlibat dalam pekerjaan-pekerjaan yang dilakukan orang tuanya. ${ }^{49}$ Selain itu tradisi yang mengajarkan anak bekerja sejak usia masih kecil, dan mudahnya peluang kerja.

Di antara penyebab yang lain juga adalah terjadinya konflik anak dengan keluarga, dan juga adanya pengaruh dari teman. ${ }^{50}$

45 Indrasari Tjandraningsih dan Popon Anarita, Pekerja Anak di Perkebunan Tembakau, cet-1 (Bandung : Akatiga, 2002), hlm. 7-8.

46 Indrasari Tjandraningsih dan Popon Anarita, Pekerja Anak., hlm. 8.

47 Indrasari Tjandraningsih dan Popon Anarita, Pekerja Anak, hlm. 9.

48 http://www.rappler.com/indonesia/135806-pekerja-anak-rantai-produksi-industri akses 23 Februari 2017

49 SAMIN, 1998, Pekerja Anak dan Penanggulangannya, Yogyakarta: Sekretariat Anak Merdeka Indonesia, hlm. 17.

50 SAMIN, Pekerja Anak., hlm. 65. 
2. Dampak Pekerja Anak Terhadap Masa Depan Anak

Resiko dan dampak kerja yang paling banyak dialami oleh anak-anak, terutama anak lakilaki adalah perlakuan kasar. Sementara itu, sakit akibat bekerja juga lebih banyak dialami lakilaki, karena beban mereka lebih berat. ${ }^{51}$

Resiko kerja dalam arti segala hal yang dialami dan akan mengganggu hingga membahayakan terhadap fisik dan psikis mereka, antara lain kecelakaan kerja, sakit, hingga perlakuan buruk yang mereka terima. Perlakuan tersebut pada umumnya berasal dari orang dewasa yang bekerja bersama mereka sehari-hari yaitu orang tua terutama ayah, buruh dewasa, mandor, atau asisten.

Sedikitnya masih ada lima alasan utama lainnya yang mendorong permasalahan pekerja anak selalu dijadikan bahasan penting, karena melihat dampak yang akan dialaminya.

Pertama, meningkatnya jumlah pekerja anak akan memicu hambatan dinamika proses pembangunan SDM di masa depan. Dampaknya sangat besar, utamanya sosial cost yang diderita pekerja anak dan hilangnya kesempatan untuk memasuki dunia sekolah.

Kedua, perlunya mengantisipasi secara dini persoalan yang mungkin timbul akibat bertambahnya jumlah absolut pekerja anak dari waktu ke waktu, yaitu persoalan ketenagakerjaan dalam kontek kendala investasi.

Ketiga, Pertambahan jumlah pekerja anak berpengaruh terhadap pasar tenaga kerja. Akan mengurangi kesempatan kerja pada pekerja dewasa, akibat dari hasil produktifitas pekerja anak ternyata tidak jauh berbeda dengan produktifitas pekerja dewasa. Dari aspek ekonomi, pihak pengusaha sangat diuntungkan dengan banyaknya pekerja anak, yaitu dengan pambayaran upah yang rata-rata lebih rendah, tidak banyak menuntut bahkan tidak mengetahui apa yang menjadi haknya sebagai pekerja.

Keempat, masih sebatas perdebatan, yaitu tentang eksploitasi pekerja anak oleh perusahaan pada umumnya di satu sisi. Sementara pendapat lain mengatakan mereka memang menunjukkan etos kerja yang lebih tinggi, sehingga seringkali pekerja anak memiliki waktu kerja yang jauh melebihi ketentuan yang ada.

Kelima, semakin banyak pekerja di bawah umur membuka peluang untuk eksploitasi tenaga anak-anak. Mereka tidak mengetahui hak-haknya sebagai pekerja, seperti hak cuti, klaim asuransi dan sebagainya, yang terkait dengan peningkatan kesejahteraannya. Tingkat upah yang diterima relatif di bawah rata-rata upah pekerja dewasa, meski produktifitasnya melebihi pekerja dewasa, sehingga tidak mencerminkan beban kerja yang mereka bawa. ${ }^{52}$.

Dampak lain dari pekerja anak adalah sering menghadapi kondisi kerja yang tidak sehat, tekanan atau ancaman orang lain luka atau sakit. Dalam penelitian Irwanto dan Pardoen mencatat anak-anak gadis yang bekerja di pabrik mengeluh sakit pinggang atau tangan gemetar, dan rasa sakit yang tidak hilang setelah tidur.

Pekerja anak juga membawa dampak buruk bagi anak-anak baik secara fisik maupun psikis,

51 Indrasari Tjandraningsih, Popon Anarita, pekerja anak, hlm. 124.

52 Hardius Usman, Pekerja Anak, hlm. 73-74. 
lebih jauh bekerja di usia dini, akan mengganggu masa depan anak-anak. Kerja keras dan kasar yang mereka lakukan pun berdampak pada kesehatan mereka. Anak-anak yang bekerja di proyek bangunan mengalami hambatan pertumbuhan badan dan kecerdasan. Belum lagi mereka harus menghirup zat-zat berbahaya yang di sekitar lokasi proyek.

Bahkan, Yayasan Bina Potensi Masyarakat, di Malang mendapati 21,7 persen dari 110 pekerja anak di Wagir mengidap penyakit pernapasan. Antara lain sesak napas, tonsilitis, infeksi saluran pernapasan, hingga TBC. Lalu, sekitar 33,8 persen anak kerap menderita sakit kepala dan tekanan darah rendah. Tekanan kerja dan lingkungan kerja yang tak sehat, ditambah kurangnya istirahat, membuat ketahanan tubuh anak-anak yang bekerja sangat lemah. Sedangkan 25,7 persen dari mereka banyak terserang sakit gigi akibat mengunyah makanan sembarangan. ${ }^{53}$

Melihat jenis pekerjaan anak-anak yang dieksploitasi di Indonesia, maka dapat dipastikan dampak yang disebutkan di atas juga mengancam pekerja anak di Indonesia. Pekerja di Jermal misalnya, bukan hanya menggunakan segenap tenaganya, tetapi juga terancam jiwanya. Bahwa pekerja anak dengan beban fisik yang berat selama bertahun-tahun dapat menghambat perawakan fisik anak-anak hingga 30\% dari potensi biologis mereka, karena mereka mengeluarkan cadangan stamina yang harus bertahan hingga masa dewasa.

Beban kerja yang berat, siksaan, dan tekanan psikis yang dirasakan anak-anak yang bekerja di Jermal, tidak jarang membuat anak-anak tersebut putus asa. Mereka nekad melarikan diri, menghadang bahaya lautan dengan berenang sejauh kurang lebih 12 mil untuk menuju pantai. Apa yang dilakukan anak-anak tentunya beresiko tinggi terhadap keselamatan jiwanya.

Di sektor jasa terutama hotel dan hiburan, bahwa anak-anak direkrut berdasarkan penampilan, dan berkemampuan untuk menjalin hubungan dengan orang lain. Mereka harus melayani para pelanggan yang kebanyakan orang dewasa, sehingga mungkin berpeluang untuk mengalami rayuan seksual. Sedangkan di pabrik-pabrik atau areal perkebunan, potensi kekerasan seksual dan fisik, terutama bagi pekerja anak perempuan, bertambah bila mereka bekerja lembur atau bekerja di malam hari, dan bila tinggal dalam pengawasan ketat para mandor pria dewasa. Permasalahan anak yang bekerja persoalannya bukan pada kegiatan kerja itu sendiri melainkan pada akibat-akibat yang buruk dari kegiatan bekerja dalam usia kanakkanak terhadap perkembangan kognitif, emosi, sosial, dan fisik mereka. Hal yang menonjol adalah adanya eksploitasi terhadap pekerja anak.

Bentuk-bentuk yang dapat dilihat sebagai indikator dari ekploitasi misalnya:

1) Bekerja terlalu muda (misal mulai usia 5 tahun) yang menghambat kesempatan mendapat pendidikan dan menghambat perkembangan sosial dan psikologi mereka.

2) Bekerja dengan waktu yang panjang.

3) Bekerja terlalu lama di satu tempat tertentu tanpa waktu untuk bermain dan rekreasi.

4) Bekerja dalam situasi yang menghambat kepercayaan diri mereka, sebagai contoh adalah bounded labour atau buruh terpasung.

53 Adi Eko Warsono, Ribuan Pekerja Anak di Malang terancam Penyakitan, http://www, tempointeraktif. com/hg/ekbis/2003/07/08/brk.20030708-13,id.html, akses 3 Agustus 2005. 
5) Bekerja sebagai pengganti buruh dewasa. ${ }^{54}$

Hasil dari berbagai penelitian, pemberitaan media massa dan pengalaman pelaksanaan program aksi terhadap pekerja anak banyak menjumpai bentuk-bentuk eksploitasi seperti disebutkan di atas. Pada realitasnya juga banyak dijumpai situasi yang memiliki pengaruh buruk terhadap pekerja anak seperti tindakan kekerasan, penculikan, penyekapan dan sebagainya.

Sebagaimana Organisasi Perburuhan Internasional (ILO) mengungkapkan anak-anak usia 5-7 tahun masih banyak yang dipekerjakan dalam pekerjaan yang berbahaya. Di Indonesia, hasil pendataan Badan Pusat Statistik menunjukkan bahwa 1,7 anak-anak adalah pekerja. "Pekerja anak ditemukan hampir di semua kabupaten," ujar Patrick Daru, Chief Technical Adviser of the ILO Education and Skill Program, Menurut catatan ILO, paling tidak dari 215 juta pekerja anak, 115 juta bekerja di tempat berbahaya di seluruh dunia. Terjadi peningkatan pekerja anak di daerah bahaya dengan usia15 17 tahun."Hampir 60 persen anak bekerja ditempat berbahaya adalah laki laki," ujarnya. Sektor yang mempekerjakan anak-anak ditempat berbahaya,diantaranya sektor pertambangan, penggalian, pertanian, perikanan, pelayanan rumah tangga, dan industri jasa. Penggunaan tenaga kerja anak sangat berisiko besar dalam kecelakaan kerja." Anak-anak punya risiko besar dalam kecelakaan kerja,"ujarnya.

Ia mengapresiasi adanya keputusan Menteri Dalam Negeri tahun 2009 yang mendorong berbagai komite aksi menghapus pekerjaan buat anak, menarik, dan mengawasi anak yang jadi pekerja terutama di tempat berbahaya. Selain itu, terjadi penurunan pekerja anak perempuan di tempat berbahaya. "Pemangku kepentingan perlu segera mengatasi hal ini," tambahnya. ${ }^{55}$

4. Konsep Maslahah Terhadap Pekerja anak

Pesan dasar dan fundamental dari bangunan pemikiran hukum Islam (fiqih) adalah kemaslahatan, kemaslahatan kemanusiaan universal, atau dalam ungkapan yang lebih operasional "keadilan sosial" tawaran teoritik (ijtihad) apapun dan bagaimanapun, baik didukung dengan nas maupun tidak, yang bisa menjamin terwujudnya kemaslahatan kemanusiaan (termasuk anak-anak) dalam perspektif Islam adalah sah, dan umat Islam terikat untuk mengontrol dan merealisasikannya. Sebaliknya, tawaran teoritik apapun dan bagaimanapun, yang secara menyakinkan tidak mendukung terjaminnya kemaslahatan, lebih lebih membuka kemungkinan terjadinya kemadaratan (Fath az-Zari 'ah), dalam kacamata Islam adalah fasid, sehingga umat Islam secara individu maupun kolektif terikat untuk mencegahnya. ${ }^{56}$

Dengan paradigma di atas, maka setiap pengambilan satu keputusan hukum agama, hendaknya mempertimbangkan aspek maslahah dan mafsadahnya sebagai batang tubuh (maqasid as-Syari' 'ah).

Dalam tawaran asy-Syatibi, cara untuk memahami maqasid as-Syari' ah diantaranya

54 SAMIN, Pekerja Anak dan Penanggulangannya..., hlm. 8.

55 http://www.indonesiaheadlines.com/news/jumlah-pekerja-anak-di-indonesia-masih-tinggi-160akses 1 Juli 2011.

56 Masdar Farid Mas`udi, ”Meletakkan kembali Maslahat sebagai Acuan Syari ah, Jurnal Ulumul Quran No. 3 Vol. VI (1995), hlm. 99. 
adalah penelaahan $i$ 'llah an-Nur (perintah), dan an-Nahi (larangan), yang terdapat dalam nas al-Qur'an dan al-Hadis. ${ }^{57}$

Bagi asy-Syatibi 'illah mengandung arti yang sangat luas, yakni kemaslahatan dan hikmah yang berkaitan dengan al-Awamir (perintah-perintah), al-Ibahah (kebolehan) dan al-Mafasid yang berkaitan dengan an-Nawahi (larangan-larangan). Ini berarti bahwa 'illah suatu hukum termasuk kemaslahatan dan kemafsadahan. ${ }^{58}$

Dalam kaitan pertimbangan maqasid as-Syari' ah dalam konsep asy-. Syatibi adalah dengan memperhatikan aspek lafdhi (bahasa) dan aspek ma 'nawi. Pengertian 'illah yang dikemukakan oleh asy-Syatibi, apabila kita kaitkan dengan usaha pemahaman maqasid asSyari' ah, akan menunjukkan adanya hubungan yang kuat dan mampu membentuk suatu mekanisme pengembangan hukum yang dinamis. Karena 'illah dalam arti kemaslahatan dan kemafsadahan secara umum merupakan maqasid as-Syari' 'ah itu sendiri. ${ }^{59}$ Kesan inilah tersirat pada ayat al-Qur’an:

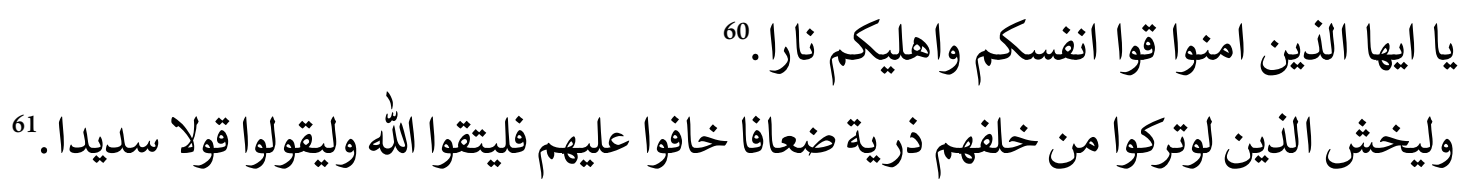

Pemahaman yang diperoleh dari nas-nas di atas adalah perintah menjaga keluarga (termasuk anak-anak), agar terhindar dari siksa api neraka, kemadharatan dan kesengsaraan. Sebaliknya hendaknya dibangun keluarga (terutama anak-anak) yang berkualitas, baik keberimanan, ketakwaan maupun intelektualnya. Ini menunjukkan para orang tua wajib mendidik anak-anak dengan sungguh-sungguh, demi menjaga keturunan demi masa depan mereka, sehingga tidak melahirkan generasi yang lemah sebagaimana peringatan ayat kedua di atas.

Mencapai generasi berkualitas perlu dilindungi dan dirawat agar tidak terjebak pada pekerjaan yang membahayakan pada jiwa dan raga mereka.

Dalam hukum Islam dinyatakan bahwa merawat dan mendidik anak adalah wajib, karena apabila anak yang masih kecil tidak dirawat dan dididik dengan baik, maka akan berakibat buruk pada diri anak, bahkan bisa menjerumus kepada kehilangan nyawa mereka. ${ }^{62}$

Nyawa anak akan menjadi hilang, apabila membiarkan anak bekerja dengan kondisi yang membahayakan dan memprihatinkan baik fisik maupun psikisnya, sebab upah rendah dan waktu kerja yang panjang (12-13 jam per hari) yang akan mengancam pada jiwa anak, hal tersebut tidak sesuai dengan dengan maqasid as-Syariah yang merupakan kebutuhan ḍharuriyyah (primer) di antaranya yaitu untuk menjaga jiwa anak, karena mereka masih butuh perlindungan dari orang tua.

Menjaga agama, di usia dini dilarang untuk bekerja, karena dapat menyebabkan dirinya 57 Abu Ishaq asy-Syatibi, t.t. Aal-Muwäfaqātfi Usül asy-Syarīah, Kairo: Mustafa Muhammad, Jilid II, hlm. 394. 58 Asy-Syatibi, Al-Muwäfaqat, I: hlm. 265.

59 Asafri Jaya Bakri, 1996, Konsep Maqasid Syariah menurut As-Syatibi, Jakarta: Raja Grafindo Persada, hlm. 97. 60 At-Tahrim (66): 6.

61 An- Nisa' (4): 9.

62 Abdul Aziz Dahlan (ed), 1996, Ensiklopedi Hukum Islam, cet ke-1, Jakarta: Ichtiar Baru Van Hoeve, hlm. 415. 
terbengkalai untuk menjalankan ibadah kepada Allah maupun berbuat baik kepada sesama. Ini disebabkan dengan waktu kerja yang panjang lebih dari 40 jam per minggu, padahal anak seharusnya kerja hanya 20 jam perminggu. ${ }^{63}$ Kerja yang dimaksud juga dalam bentuk yang ringan dan dalam pengawasan pengusaha maupun orang tua secara ketat. ${ }^{64}$ Karena mereka telah terjebak ke dunia yang seharusnya mereka tidak terjun, sebab belum saatnya, hal tersebut adalah tugas orang tua.

Menjaga keturunan, dengan bekerja di usia kanak-kanak, akan menyebabkan generasi yang lemah dan tidak berpendidikan serta membuat fisik anak-anak tidak sehat, sebab waktunya habis digunakan untuk bekerja. Hal ini akan semakin menyebabkan kemiskinan dan generasi yang rapuh. ${ }^{65}$

Menjaga akal, banyaknya beban kerja yang mereka tanggung dengan mengorbankan akal dan pikirannya untuk tidak sekolah sehingga pikiran dan wawasannya terbatas. Anak-anak yang seharusnya mendapat perlindungan penuh tidak mereka dapatkan. Mereka, tanpa pendidikan sesungguhnya semakin tidak mendapatkan kesempatan merubah nasib sehingga tetap miskin. ${ }^{66}$

Dalam al-Qur'an juga dijelaskan:

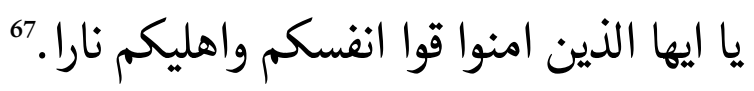

Tanggung jawab terhadap anak merupakan kewajiban orang tua untuk menjaga keluarganya dari api siksa neraka, karena keluarga merupakan satuan unit terkecil dalam hidup bermasyarakat, keberadaannya tentu akan membawa pengaruh terhadap terbentuknya suatu masyarakat. Oleh karena itu orang tua memikul kewajiban yang luhur untuk menegakkan rumah tangga yang menjadi dasar dari susunan suatu masyarakat. ${ }^{68}$ Melindungi pekerja anak dari pekerjaan yang buruk merupakan kebutuhan Dharuriyyah sehingga orang tua selalu melindungi dan merawat dari hal-hal yang membahayakan, termasuk menjadi pekerja anak.

Dalam kaidah usuliyah dijelaskan:

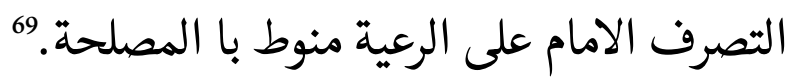

Apabila orang tua, kerabat maupun masyarakat sudah tidak mampu memberi nafkah pada anak, maka hal tersebut menjadi kewajiban bagi pemimpin untuk melindungi dan menjaganya, demi kemaslahatan anak tersebut.

Dalam Undang-undang Dasar 1945 dinyatakan,"fakir miskin dan anak terlantar dipelihara oleh negara", hal tersebut memberikan arti bahwa apabila orang tua tidak mampu mengasuh dan memelihara dan mendidik anak, maka pemerintah wajib melindungi dan bertanggung

63 Hardius Usman, pekerja anak..., hlm. 33.

64 Undang-undang Ketenagakerjaan No. 13 Tahun 2003 Pasal 69.

65 http;//www.ilo-jakarta.or.id/Indonesia/iloipec/whatipecchildlabour.htm, akses 3 Agustus 2005.

66 Hardius Usman Pekerja Anak di Indonesia..., hlm. 1.

67 At-Tahrim (66) : 6.

68 Mohammad, Idris Ramulyo, 1996, Hukum Perkawinan Islam, cet. ke-1, Jakarta: Bumi Aksara, hlm.187188.

69 Asmuni A. Rahman, Qawaidul Fiqhiyah, hlm.60. 
jawab memberikan pendidikan dan penghidupan bagi anak-anak yang terlantar. ${ }^{70}$

Manusia sebagai khalifah di bumi, untuk mengemban amanah Allah, dan menegakkan agama Allah dengan menjadikan hidup di dunia damai dan tenang. Allah juga telah berfirman:

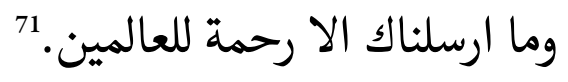

Dengan kata lain, bahwa permasalahan pekerja anak tidak boleh dibiarkan. Dengan demikian perlindungan bagi pekerja anak harus diupayakan, mengingat pemerintah Indonesia memberikan perlindungan hukum bagi pekerja anak, hanya penindakan terhadap pelanggarpelanggarnya belum dapat dilakukan sebagaimana mestinya. Sehingga kasus black market sering terjadi. Seharusnya mereka harus belajar demi masa depannya. Adapun bentuk-bentuk perlindungannya adalah:

\section{Kesimpulan}

Anak harus dilindungi, dengan alasan bahwa orang tua wajib melindungi dan memberi nafkah Q.S. al- Baqarah (2): 233, apabila orang tua tidak mampu kerabat terdekat wajib melindungi, sebab berhubungan dengan waris.Q.S. al-Baqarah (2): 233. Selain itu kondisi para pekerja anak yang buruk dan memprihatinkan serta membahayakan kesehatan, keselamatan kerja, moral dan perkembangan psikologi anak. Sebab bekerja dengan waktu kerja yang panjang, dan upah rendah, serta sering terjadi eksploitasi menyebabkan anak tidak mempunyai kesempatan untuk menikmati pendidikan, mendapatkan kasih sayang dari orang tua, maupun bermain menikmati masa kanak-kanaknya.

Meskipun kemiskinan yang sering dijadikan alasan terjunnya pekerja anak, namun semua itu merampas hak-hak anak. Dengan anak yang bekerja sebelum waktunya, akan menjadikan generasi mendatang lemah, hal tersebut tidak sesuai dengan konsep maqasid asy-Syari'ah di antaranya menjaga dari lima hal, yang masuk dalam salah satu kebutuhan $d$ f haruriyyah yaitu menjaga jiwa anak. Dikuatkan juga dengan nas-nas al-Qur'an. Dampak dari pekerja anak baik dalam jangka pendek maupun jangka panjang, tentunya sangat merugikan baik fisik maupun psikisnya, Q.S. an-Nisa'(4): 9 Hal tersebut di atas yang menjadi pijakan tidak diperbolehkannya pekerja anak. Sebagai bentuk perlindungan jiwa yang merupakan kebutuhan $d\}$ haruriyyah. Meskipun pekerja anak dapat membantu perekonomian keluarga, demi keberlangsungan hidup, akan tetapi pekerja anak harus dihindari mengingat madaratnya lebih besar dibanding maslahatnya. Namun apabila dalam rangka membantu orang tua dan tidak menggangu jiwa maupun fisiknya maka diperbolehkan.

70 Undang-undang No. 23 Tahun 2002 tentang Perlindungan Anak, pasal 53-56.

71 Al Anbiya' (21);107 
$60 \mid$ Indar Wahyuni

\section{BIBLIOGRAFI}

Ahmad al- Barri, Zakariyya, Abkam al-Aulad fi al-Islam, (Jakarta: Bulan Bintang, t.t.)

Al- San'any, Subul as-Salam, juz 3, ( kairo: al Turas al-'araby, 1379 H/1960 M)

Andri Yoga Utami, “Fenomena Pekerja Anak yang Terselubung dan Termarginalkan” , Jurnal Perempuan, edisi 39, (Januari 2005)

Asy-Syatibi, al-Muwafaqat fi Usul al Ahkam, ( Beirut: Dar al Fikr,1341 H ) juz II,

Aziz Dahlan, Abdul (ed), Ensiklopedi Hukum Islam, cet ke-1 ( Jakarta : Ichtiar Baru Van Hoeve, 1996)

Dinas Sosial Propinsi DIY, "Perlindungan Anak oleh Negara dan Proses Pengangkatan Anak", makalah disampaikan Pada Seminar Nasional dan Rakernas FK-MASI, (yogyakarta: 2005)

http;//www.ilo-jakarta.or.id/Indonesia/iloipec/whatipecchildlabour.htm, akses 3 Agustus 2005.

Imam Muslim, Sahih Muslim, "Kitab qadar”, “ Bab Kullu min mauludin yuladu 'ala al- fitrati”. ( Beirut: dar al- Fikr, tt), II

Indrasari Djandraningsih dan Popon Anarita, Pekerja Anak di Perkebunan Tembakau, (Bandung: AKATIGA, 2002)

Ishaq asy-Syatibi, Abu, Al-Muwafaqat fi Usul asy-Syariah, (Kairo: Mustafa Muhammad, t.t.), II :

Jaya Bakri, Asafri, Konsep Maqasid Syariah menurut As-Syatibi, ( Jakarta: Raja Grafindo Persada, 1996)

Khalid Mas'ud, Muhammad Filsafat Hukum Islam dan Perubahan Sosial, alih bahasa, W.Asmin, ( Surabaya: al Ikhlas, 1995)

Khalid Mas'ud, Muhammad, Filsafat Hukum Islam Studi tentang Hidup dan Pemikiran Abu Ishaq Asy-Syatibi, (Bandung: Pustaka, 1996)

M Sumijati dkk,(ed), Manusia dan Dinamika Budaya dari Kekerasan sampai Baratayuda, (Yogyakarta: Fakultas Sastra UGM, 2001)

Masdar Farid Mas`udi, "Meletakkan kembali Maslahat sebagai Acuan Syari`ah, Jurnal Ulumul Quran No. 3 Vol. VI (1995),

Mif Baihaqi, (ed,) Anak Indonesia Teraniaya, (Bandung: Remaja Rosda Karya, 1999)

Miharet, Gaston, Hak-hak Anak untuk Memperoleh Pendidikan, alih bahasa Idris M.T. Hutapea (Jakarta: Balai Pustaka, 1993) 
Poerwadarminto, WJS. Kamus Besar Indonesia, (Jakarta: Balai Pustaka, 1982),

Rajih, Hamdan, Mengakrabkan Anak dengan Tuhan Menghantarkan Generasi Muda ke Jalan Surgawi, alih bahasa, Abdul wahid hasan (Yogyakarta: Diva Press, 2002)

Rofiq, Ahmad, Hukum Islam di Indonesia, cet.2 (Jakarta: Rajawali Pres, 1997)

SAMIN, Pekerja Anak dan Penanggulangannya, (Yogyakarta: Sekretariat Anak Merdeka Indonesia, 1998)

Suyanto, Bagong, Pekerja Anak dan kelangsungan Pendidikannya, cet. Ke-1 ( Surabaya: Airlangga Press, 2003)

Suyanto, Bagong, Pelanggaran Hak dan Perlindungan Sosial bagi Anak Rawan, cet.ke-1 (Surabaya: Airlangga Press, 2003)

Usman Nachrowi Djalal Nachrowi, Hardius, Pekerja Anak di Indonesia :Kondisi Determinan dan Eksploitasi: Kajian Kuantitatif, ( Jakarta: PT Grasindo Widiasarana Indonesia, 2004)

UU Ketenagakerjaan No.13 Th.2003

Yafie, Ali Teologi Sosial: Telaah Kritis Persoalan Agama dan Kemanusiaan, (Yogyakarta: LKPSM, 1997)

Yayasan Sekretariat Anak Merdeka Indonesia, Pekerja Anak dan Penanggulangannya (Yogyakarta: Samin, 1998 )

Yusuf al-Qardawy, Muhammad, Konsepsi Islam dalam mengentas Kemiskinan, ( Surabaya: Bina Ilmu, 1996)

http://www.indonesiaheadlines.com/news/jumlah-pekerja-anak-di-indonesia-masih-tinggi-160 akses 1 Juli 2011

Eko Warsono, Adi Ribuan Pekerja Anak di Malang terancam Penyakitan, http://www, tempointeraktif.com/hg/ekbis/2003/07/08/brk.20030708-13,id.html, akses 3 Agustus 2005.

http://www.rappler.com/indonesia/135806-pekerja-anak-rantai-produksi-industri akses 23 februari 2017 
